\title{
Bilateral Ophthalmic Segment Aneurysm Clipping with One Craniotomy: Operative Technique and Results
}

\author{
Bilateral Oftalmik Kisım Anevrizmalarının Tek Kraniotomi ile \\ Kliplenmesi: Cerrahi Teknik ve Sonuçlar
}

\author{
Osman Arikan NACAR ${ }^{1}$, Ana RODRIGUEZ-HERNANDEZ ${ }^{1}$, Mustafa Onur ULU², \\ Ruben RODRIGUEZ-MENA ${ }^{3}$, Michael T LAWTON ${ }^{1}$ \\ ${ }^{1}$ University of California San Francisco (UCSF), Department of Neurosurgery, San Francisco, CA, U.S.A. \\ ${ }_{2}^{2}$ stanbul University, Cerrahpasa Medical Faculty, Department of Neurosurgery, Istanbul, Turkey \\ ${ }^{3}$ Hospital Universitario de la Ribera, Department of Neurosurgery, Valencia, Spain
}

Corresponding Author: Mustafa Onur ULU / E-mail: dronurulu@gmail.com

\begin{abstract}
AIM: Surgical indications for ophthalmic segment aneurysms are getting narrower due in part to success of endovascular techniques like flow diverters. Wide necks, large size, intraluminal thrombus, optic nerve compression or recurrence after endovascular therapy make the case for surgical treatment. Bilateral aneurysms are less established but worth considering surgical indication. Our objective is to review a series of bilateral ophthalmic segment aneurysms managed through a single craniotomy, describe the surgical technique and evaluate the results.

MATERIAL and METHODS: Between 1997 and 2012, 11 patients with bilateral ophthalmic segment aneurysms were treated through a single craniotomy at UCSF Medical Center. An intradural clinoidectomy was performed to expose and clip the ipsilateral aneurysm. Medially and superiorly projecting contralateral aneurysm could be clipped through the interoptic triangle without clinoidectomy. Indocyanin green videoangiography was performed routinely.

RESULTS: Eleven patients harboring 22 ophthalmic segment aneurysms were treated with a single craniotomy. Complete neck occlusion was achieved in $96 \%$ of aneurysms. One patient presenting with subarachnoid hemorrhage Hunt-Hess grade 5 died from vasospasm complications. The remaining 10 patients had good outcomes $(\mathrm{mRS} \leq 2)$ after a mean 2.2 years follow up. There were no recurrences after surgical treatment. CONCLUSION: Decompressing the optic nerve, completely occluding the aneurysm neck, providing a durable repair and avoiding antiplatelet agents are the well established advantages of microsurgical management. This experience demonstrates safety and feasibility of contralateral clipping of carefully selected ophthalmic segment aneurysms, thus pointing another advantage of surgical clipping when bilateral aneurysms are diagnosed.
\end{abstract}

KEYWORDS: Bilateral aneurysm, Ophthalmic segment, Surgical clipping, Treatment

öz

AMAÇ: Oftalmik kısım anevrizmalarında cerrahi tedavi endikasyonları akım yönlendiriciler gibi endovasküler tekniklerin gelişmesiyle giderek daralmaktadır. Geniş boyunlu, büyük boyutlu, lumen içi thrombuslu, optik sinir basılı veya endovasküler cerrahi sonrası nüks olan olgularda cerrahi ön plana çıkmaktadır. Bilateral anevrizma varlığı ise daha az değerlendirilen ama cerrahi düşünülmesine değer bir durumdur. Amacımız, tek bir kraniotomi ile tedavi edilen bilateral oftalmik kıım anevrizmalı hasta serisini incelemek, cerrahi tekniği tanımlamak ve sonuçları değerlendirmektir.

YÖNTEM ve GEREÇLER: 1997-2012 yılları arasında UCSF Tıp Merkezi'nde 11 bilateral oftalmik kısım anevrizmalı hasta tek kraniotomi ile tedavi edilmiştir. İpsilateral anevrizmayı ortaya koymak ve kliplemek için intradural klinoidektomi yapılmıştır.Mediale ve superior uzanan kontrlateral anevrizmalar klinoidektomi yapılmaksızın interoptik üçgenden kliplenmiştir. Indocyanin yeşili videoanjiyografi rutin olarak kullanılmıştır.

BULGULAR: 22 oftalmik kısım anevrizması olan 11 hasta tek kraniotomi ile tedavi edildi. Hastaların \% 96'sında anevrizma boynu tam kapatıldı. Hunt-Hess evre 5 subaraknoid kanama ile başvuran bir hasta vazospazm komplikasyonları nedeniyle kaybedildi. Geri kalan 10 hastanın ortalama 2,2 yıl takiplerinde sonuçları iyiydi $(\mathrm{mRS} \leq 2)$.Cerrahi tedavi sonrası nüks saptanmadı.

SONUÇ: Optik sinir dekompresyonu, anevrizma boynunun tamamen tıkanabilmesi, dayanıklı bir tamir oluşturması ve antiplatelet ajan kullanımı gerektirmemesi mikrocerrahi tedavinin iyi bilinen avantajlarıdır. Bulgularımız cerrahi tedavinin bir başka avantajını gösterecek şekilde iyi seçilmiş bilateral oftalmik kısım anevrizmalarında kontrlateral kliplemenin güvenli ve etkin olduğunu göstermektedir.

ANAHTAR SÖZCÜKLER: Bilateral anevrizma, Cerrahi klipleme, Oftalmik kısım, Tedavi 


\section{INTRODUCTION}

Ophthalmic artery (OphA) and superior hypophyseal artery (SHA) aneurysms originate from the ophthalmic segment of the internal carotid artery (ICA) between the distal dural ring and the takeoff of the posterior communicating artery $(1,3,5,15)$. Microsurgical clipping of these aneurysms remains challenging due to their anatomical complexity, the need for anterior clinoidectomy, poorly accessible proximal control, the need for complex clip configurations like rightangle fenestrated clipping, and proximity to vital structures, including optic nerve, carotid artery, and cavernous sinus. Surgical results with ophthalmic segment aneurysms have improved with advances in microsurgical technique and anatomical research $(2,4,6,8,13,14)$, but so too have endovascular results, especially with the introduction of stentassisted coiling and flow diverters. Early experiences with the pipeline embolization device and other similar devices have been favorable in the ophthalmic segment, limiting surgical indications to aneurysms with wide necks, large or giant size, intraluminal thrombus, optic nerve compression, recurrence after prior endovascular therapy, and contraindication to antiplatelet therapy. An additional surgical indication is bilaterality: a contralateral aneurysm can often be clipped easily through the interoptic triangle during the same craniotomy and spare the patient a second craniotomy or additional intervention. Ophthalmic segment aneurysms are uncommon $(5-11 \%$ of all intracranial aneurysms (1, $7,12,19)$ and $6 \%$ of the senior author's experience), but bilateral ophthalmic segment aneurysms are encountered in $7.5-21 \%$ of these patients $(1,12)$. Yasargil et al. reported the contralateral approach to ophthalmic segment aneurysms in 1977 (19), and many authors have reported their experience since $(1,5,9-11,15-18)$. However, few authors have reported their results with unilateral craniotomy for bilateral ophthalmic segment aneurysms and the available literature is mainly in the form of case reports. We present an experience with 11 such patients and emphasize the operative nuances of anterior clinoidectomy and contralateral dissection.

\section{MATERIAL and METHODS}

This study was approved by the University of California, San Francisco Committee on Human Research and performed in compliance with Health Insurance Portability and Accountability Act (HIPAA) regulations. Patients harbouring ophthalmicsegmentaneurysms whounderwentmicrosurgical treatment were identified from the prospectively maintained Vascular Neurosurgery database. Between 1997 and 2012, 11 patients with bilateral ophthalmic segment aneurysms were treated through a single craniotomy by the senior author (MTL) at the UCSF Medical Center. Operative reports, inpatient charts, radiological imaging data (DSA, CTA, MRI, CT...etc), intraoperative photographs, and outpatient clinic data were analyzed retrospectively. Neurological outcomes were assessed using the modified Rankin score (mRS). Functional outcome was defined as good ( $\mathrm{mRS} 0$ to 2 ; independent) or poor (mRS 3 to 6; dependent or dead). A clinical research assistant or clinician not directly involved in the care of these patients performed all outcome assessments preoperatively, early postoperatively (6 weeks), and at last available followup.

\section{Surgical Technique for Anterior Clinoidectomy}

A standard pterional craniotomy is performed under general anesthesia. The head is positioned with less than normal head extension, allowing a direct view of the superior aspect of the anterior clinoid process (ACP). The cervical carotid artery is prepared and draped into the field in case proximal carotid exposure is need for control. Intraoperative monitoring of the electroencephalogram (EEG) and the somatosensory-evoked potentials demonstrate tolerance or brain ischemia when temporary occlusion of the ICA is required.

Anterior clinoidectomy can be performed intradurally or extradurally. Extradural clinoidectomy maintains the dural layer during drilling to protect the brain and cortical vessels, and keep bone dust and clinoid bleeding out of the subarachnoid space. Brain retraction is better tolerated when extradural. However, the aneurysm is hidden from view, which can promote intraoperative rupture and make it more difficult and time consuming to control. In contrast, intradural clinoidectomy provides an encompassing view of the ACP, ICA, and optic nerve, which helps protect them during clinoidectomy. Intradural clinoidectomy was performed in all of our cases.

The proximal Sylvian fissure is opened widely to display ICA bifurcation and proximal middle cerebral artery (MCA). Draining cerebrospinal fluid (CSF) from the subarachnoid space allows relaxation of the brain and provides a wide corridor into the basal cisterns. This minimizes or eliminates the need for retraction of the frontal lobe and provides a wide working space at the depth of the dissection. The arachnoid around the optic nerve is deliberately preserved to protect its delicate perforators.

Superficial dura on the ACP is incised in an arc that extends from the tip of the ACP posteriorly to the sphenoid ridge laterally (Figure 1A. Step 1). This dural incision extends posteriorly into the oculomotor triangle and down to the oculomotor sheath to completely uncover the posterior tip of ACP. A second dural incision is made from the middle of the first cut, arching medially across the roof of the optic canal onto the planum sphenoidale to the medial aspect of the falciform ligament. Two dural flaps are elevated with round knives. Then optic canal is unroofed with a high-speed diamond drill under copious saline irrigation (Figure 1B. Step 2). Early decompression of optic nerve improves the nerve's tolerance to clinoidal dissection later and relieves pressure and distortion from the aneurysm. Then ACP's cancellous core is drilled away and its cortical margins are thinned, breaking its attachments medially to the optic canal and laterally to the sphenoid ridge (Figure 1B. Step 3). The optic sheath is dissected off the floor of the optic canal and the ACP is fractured up from inferior attachments to the optic strut. The dural adhesions around ACP are released and it is removed 
(Figure 1C. Step 4). Venous bleeding from the cavernous sinus through the carotid-oculomotor membrane is controlled with packing or injection of fibrin glue. The cut initiating the dural ring incision begins in the dura lateral to the mouth of the optic sheath and converges on the lateral border of the sheath (Figure 1C. Step 5). More anterior cuts lead to the optic strut (Figure 1D. Step 6). The optic strut fills the space in front of the clinoidal segment of the ICA and below the dural ring. Resecting the optic strut opens a space that transforms the ring from a bony lining to a free tissue layer. Moreover, bony reduction of the strut allows the dural ring to mobilize anteriorly, opening and incision pathway for the microscissors' superior blade on the subarachnoid side of the ring. The optic strut is progressively drilled away with a 1-mm-diameter round diamond-tipped bit until the dissection drops medially around the clinoidal ICA into the carotid sulcus. The distal dural ring crosses the ICA anterior to OphA origin (Figure 1E. Step 7). This artery is elevated off the dura of the ring and canal floor before it is cut because it can adhere to or fuse with this dura. After incising under the OphA, the ring's medial-
A

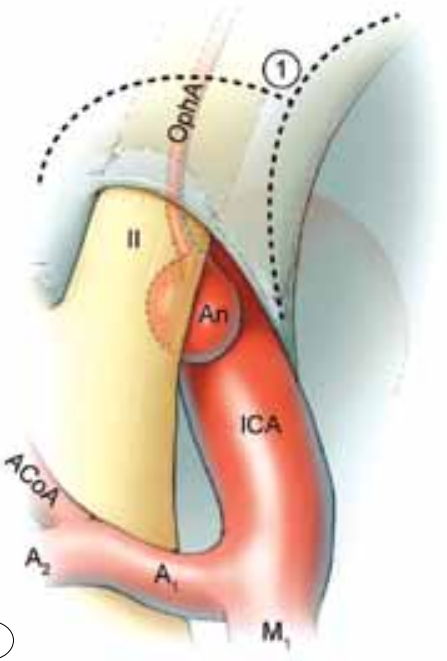

(B)

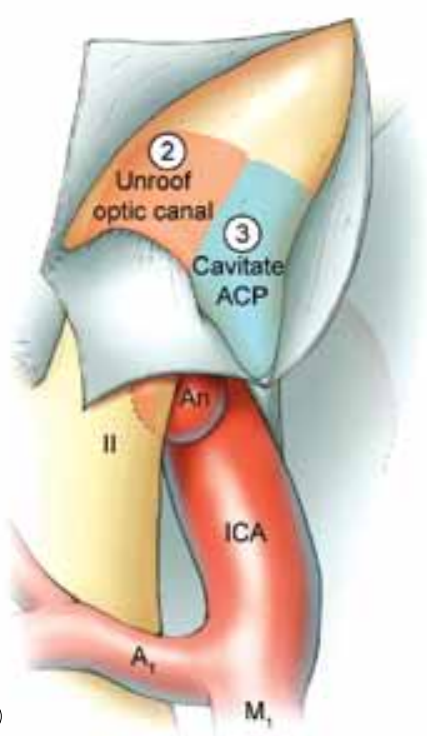

(C)

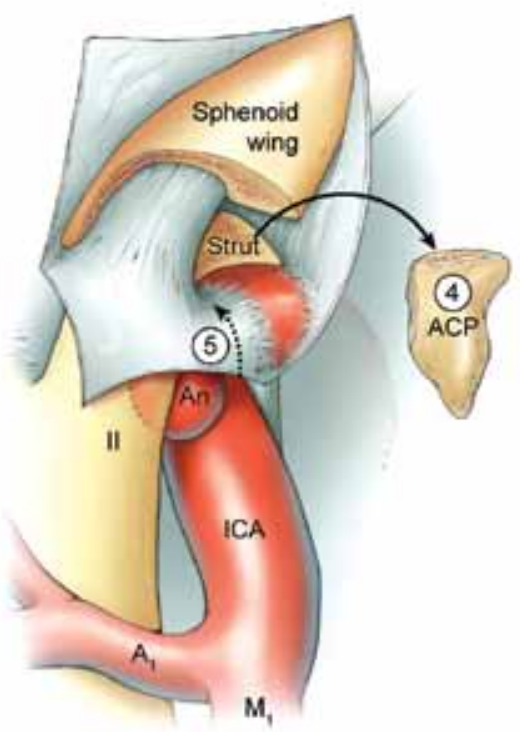

(D)

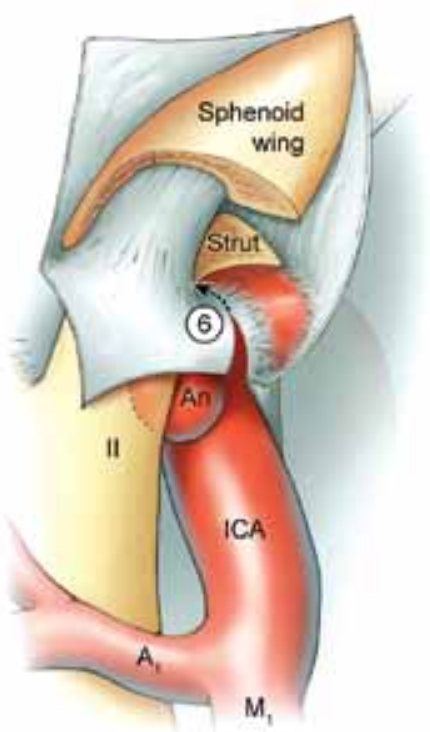

(E)

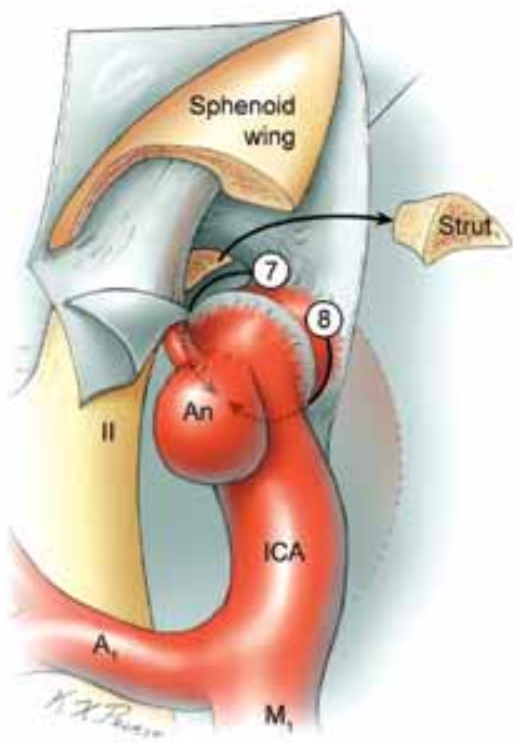

Figure 1: Anterior Clinoidectomy Technique. A) An incision is made in the dura overlying the anterior clinoid as shown by the dash line. B) A diamond $3 \mathrm{~mm}$ bit drill is used to unroof the optic canal and cavitate the anterior clinoid. C) The anterior clinoid is removed and D) the distal dural ring is opened. E) The distal dural ring is dissected superiorly and medially, which allows more of the optic strut to be removed. Additional dissection laterally and inferiorly mobilizes the carotid artery. 
inferior-posterior course can be hidden by the OphA and the ICA. The dissection pathway should remain in the axilla of the OphA and follow the clinoidal ICA to the bony carotid sulcus, defining the ring along its proximal side. A dissection pathway over the shoulder of the OphA can disrupt perforators to the undersurface of the optic nerve and is avoided. A vanishing medial view of the dural ring and venous bleeding are offset by a thinner ring that is easier to cut. These last medial cuts that complete the dissection of the upper half of the ring are critically important because they de-tether the ICA and open a blade path with SHA aneurysms.

The dissection returns to the dural ring laterally to incise lower half of the ring (Figure 1E. Step 8). Initial cuts in this direction are easy to see, but inferior and medial cuts adjacent to the cavernous and intercavernous sinuses can cause venous bleeding. It is difficult for the inferomedial dissection to join previous superomedial cuts, but a completely circumferential incision is only needed for SHA aneurysms. After dural ring dissection, the proximal and distal neck of the aneurysm is dissected and the ipsilateral aneurysm is clipped.

Attention is then turned to the contralateral aneurysm. First, the ipsilateral A1- ACA segment is identified and followed to the anterior communicating artery complex. The lamina terminalis is then fenestrated releasing cerebrospinal fluid to slacken the brain for easier frontal retraction. The interoptic triangle is opened widely, exposing the medial wall of the contralateral ophthalmic ICA segment. The contralateral OphA aneurysm is identified underneath the optic nerve. The aneurysm and/or the parent segment may need to be mobilized to visualize the neck. In such case, just as in the ipsilateral dissection, mobilizing the ICA is always preferable to manipulation of the optic nerve. Manipulation is poorly tolerated by the optic nerve, particularly when already deflected by the aneurysm. Instead, gentle pressure downward and slightly laterally moves the ICA to allow advancing the aneurysm neck dissection. Medially and superiorly projecting aneurysms can easily be visualized and clipped without the anterior clinoidectomy and dural ring dissection that would have been required in an ipsilateral approach to these lesions. Permanent clipping with a single slightly curved clip is usually feasible and safe. Following clipping of both the ipsilateral and contralateral aneurysms, indocyanine green videoangiography is routinely performed for all patients to confirm absence of aneurysm filling and flow in parent artery and branch arteries.

Table I: The Demographic Features, Presenting Symptoms and Signs

\begin{tabular}{|c|c|c|c|c|c|c|c|c|c|}
\hline $\begin{array}{c}\text { Patient } \\
\#\end{array}$ & $\begin{array}{l}\text { Age/ } \\
\text { Sex }\end{array}$ & $\begin{array}{l}\text { Presenting } \\
\text { Sx }\end{array}$ & $\begin{array}{l}\text { Hunt \& } \\
\text { Hess }\end{array}$ & Fisher & Hydrocephalus & $\begin{array}{c}\text { \# of } \\
\text { Aneurysms }\end{array}$ & $\begin{array}{l}\text { Rupt. } \\
\text { Side }\end{array}$ & Aneurysms & $\begin{array}{l}\text { Aneurysm } \\
\text { Size } \\
\text { R / L (mm) }\end{array}$ \\
\hline 1 & $41 / \mathrm{F}$ & None & 0 & 1 & No & 3 & None & $\begin{array}{c}\text { R/L Opht., } R \\
\text { Paraclinoid ICA }\end{array}$ & $2.5 / 3$ \\
\hline 2 & $62 / F$ & None & 0 & 1 & No & 2 & None & R/L Opht. & $6 / 5$ \\
\hline 3 & $37 / F$ & SAH & 5 & 4 & Yes & 2 & Left & R/L Opht. & $3 / 12.5$ \\
\hline 4 & $44 / F$ & None & 0 & 1 & No & 3 & None & $\begin{array}{l}\text { LOpht. } \\
\text { R Sup.Hypoph. } \\
\text { R Ant.Choroidal }\end{array}$ & $4.5 / 4$ \\
\hline 5 & $50 / \mathrm{F}$ & None & 0 & 1 & No & 2 & None & $\begin{array}{l}\text { L Sup.Hypoph. R } \\
\text { Opht. }\end{array}$ & $3.5 / 12$ \\
\hline 6 & $43 / \mathrm{F}$ & Headache & 0 & 1 & No & 4 & None & $\begin{array}{l}\text { R/LOpht., } \\
\text { R Ant.Temp., } \\
\text { R MCA }\end{array}$ & $11 / 4$ \\
\hline 7 & $55 / \mathrm{F}$ & Headache & 1 & 2 & No & 3 & Left & $\begin{array}{l}\text { R/L Opht., } \\
\text { L ICA Bifurc., }\end{array}$ & $3 / 3$ \\
\hline 8 & $54 / F$ & Headache & 0 & 1 & No & 2 & None & $\begin{array}{l}\text { R Opth. , } \\
\text { LClinoid and } \\
\text { Supraclinoid } \\
\text { ICA(post. wall) }\end{array}$ & $2.5 / 14$ \\
\hline 9 & $61 / F$ & None & 0 & 1 & No & 2 & None & R/L Opht. & $6 / 6$ \\
\hline 10 & $24 / M$ & None & 0 & 1 & No & 2 & None & $\begin{array}{l}\text { R Sup.Hypoph. } \\
\text { L Opht. }\end{array}$ & $5 / 2$ \\
\hline 11 & $47 / F$ & None & 1 & 1 & No & 2 & None & R/L Opht. & $2 / 2$ \\
\hline
\end{tabular}

Abbreviations: $R$ : right, L: left, Sx: symptom, Rupt: rupture. 


\section{RESULTS}

Eleven patients had bilateral ophthalmic segment aneurysm clipped with one craniotomy. Ages ranged from 24 to 62 years (mean, 47), and 10 were women (91\%). Two patients (18\%) presented with subarachnoid hemorrhage; two patients had prior intracranial hemorrhages, one from a ruptured posterior inferior cerebellar artery aneurysm and one intracerebral hematoma unrelated to the aneurysm; and the rest presented with headaches or incidental diagnosis (Table I). In total, 27 aneurysms were identified, including 3 patients with 3 aneurysms and 1 patient with 4 aneurysms. Ophthalmic segment aneurysms included 18 OphA aneurysms, 3 SHA aneurysms, and 1 ventral ICA aneurysm. Mean aneurysm sizes were $7.13 \mathrm{~mm}$ on the ipsilateral side and $3.45 \mathrm{~mm}$ on the contralateral side.

All patients were treated with pterional craniotomy on the side of the larger, more complex aneurysm. Ipsilateral anterior clinoidectomy was performed in all cases, and no clinoidectomy was performed on the contralateral side. Exposure of the cervical carotid artery was performed in 3 patients, one with a large, ruptured OphA aneurysm and two with large paraclinoidal aneurysms. Temporary carotid occlusion in the neck was used in two of these patients to slacken the aneurysm during clip application. 27 aneurysms were treated, all with direct clipping except for one, which was wrapped (Table II).
Of the 26 aneurysms that were clipped, 25 were completely obliterated and 1 had small neck remnants that was observed. Postoperatively, one patient experienced new vision loss in her ipsilateral eye and visual field examinations for other patients were normal. One patient who presented in coma with SAH (Hunt-Hess grade V) died in the perioperative period after complications from vasospasm and pneumonia. Good outcomes ( $m R S \leq 2)$ were observed in the remaining 10 patients. The mean duration of follow-up was 2.2 years (Table III). Some of the case examples are shown in Figures $2 \mathrm{~A}-\mathrm{H} ; 3 \mathrm{~A}-$ $\mathrm{H} ; 4 \mathrm{~A}, \mathrm{~B}$.

\section{DISCUSSION}

This report summarizes a surgical experience with bilateral ophthalmic segment ICA aneurysms treated through a unilateral craniotomy. Bilateral aneurysms along this segment are not uncommon; when surgery is indicated for an ipsilateral aneurysm, the additional effort to clip the contralateral aneurysm is minimal; patients are spared a second craniotomy and its associated morbidity; and anterior clinoidectomy is rarely needed for contralateral aneurysm clipping. The additional dissection for contralateral aneurysm clipping includes opening the interoptic triangle and occasionally some retraction on the frontal lobe to widen the exposure. The anterior clinoid process is lateral to the aneurysm, which eliminates the need for clinoidectomy when approached through the interoptic triangle. Contralateral

Table II: Aneurysm Orientation, Morphology, and the Procedures Applied during Surgery

\begin{tabular}{|c|c|c|c|}
\hline $\begin{array}{l}\text { Patient } \\
\quad \#\end{array}$ & $\begin{array}{l}\text { Orientation \& Morphology } \\
\text { Ipsilateral }\end{array}$ & $\begin{array}{l}\text { Orientation \& Morphology } \\
\text { Contralateral }\end{array}$ & Procedure \\
\hline 1 & Superior / Saccular & Superior / Saccular & R PC, Clip. of bilat Opht., R ICA \\
\hline 2 & Superior / Saccular & Superior / Saccular & R PC,Clip. of L Opht., Ant.Clin., Clip. of R Opht. \\
\hline 3 & Superior / Multilobulated & Superior / Saccular & $\begin{array}{l}\text { L PC, Cervical carotid exposure, Ant.Clin., Clip. of L } \\
\text { Opht., Wrapping of R Opht. }\end{array}$ \\
\hline 4 & Medial / Saccular & Superior / Bilobed & $\begin{array}{l}\text { R PC, Ant.Clin., Clip. of L Opht., R Sup.Hypoph., R } \\
\text { Ant. Choroidal. }\end{array}$ \\
\hline 5 & Inferomedial / Bilobed & Medial / Saccular & $\begin{array}{l}\text { L PC, Cervical carotid exposure, Ant.Clin., Clip. of L } \\
\text { Sup.Hypoph., R Opht. }\end{array}$ \\
\hline 6 & Superomedial / Saccular & Superior / Saccular & $\begin{array}{l}\text { R PC, Ant.Clin., Clip. of R Opht., R Ant.Temp., R MCA, } \\
\text { L Opht. }\end{array}$ \\
\hline 7 & Superior / Saccular & Superior / Saccular & $\begin{array}{l}\text { L PC, Clip. of L ICA Bifurc., R Opht., Wrapping of } L \\
\text { Opht. }\end{array}$ \\
\hline 8 & Inferior / Fusiform & Superomedial / Saccular & $\begin{array}{l}\text { L PC, Cervical carotid exposure, Ant. Clin., Clip } \\
\text { Reconstruction of L ICA (Posterior Wall), Clip. of R } \\
\text { Opht., Intraoperative Angiogram }\end{array}$ \\
\hline 9 & Superior / Saccular & Medial / Saccular & $\begin{array}{l}\text { L PC, Ant. Clin., Clip. of L Opht., R Opht. ICG } \\
\text { Angiography }\end{array}$ \\
\hline 10 & Superomedial / Saccular & Superior / Saccular & $\begin{array}{l}\text { R PC, Ant. Clin., Clip. of R Opht., L Opht. ICG } \\
\text { Angiography }\end{array}$ \\
\hline 11 & Anteriosuperior / Saccular & Anteriosuperior / Saccular & R PC, Extradural Ant. Clin., Clip. of R Opht., L Opht. \\
\hline
\end{tabular}

Abbreviations: R: right, L: left, PC: pterional craniotomy, Ant.Clin: anterior clinoidectomy. 
Table III: Other Surgical Characteristics and Clinical Outcome

\begin{tabular}{|c|c|c|c|c|c|c|c|}
\hline $\begin{array}{c}\text { Patient } \\
\#\end{array}$ & $\begin{array}{l}\text { Optic Nerve } \\
\text { Movement } \\
\text { Ipsilat / Contr }\end{array}$ & $\begin{array}{l}\text { Visual Field } \\
\text { Preop. }\end{array}$ & $\begin{array}{l}\text { Visual Field } \\
\text { Postop. }\end{array}$ & $\begin{array}{c}\text { m RS } \\
\text { score } \\
\text { Preop. }\end{array}$ & $\begin{array}{c}\text { m RS } \\
\text { score } \\
\text { Early Postop. }\end{array}$ & $\begin{array}{c}\text { m RS } \\
\text { score } \\
\text { Last Follow up }\end{array}$ & $\begin{array}{c}\text { Follow Up } \\
\text { (Years) }\end{array}$ \\
\hline 1 & No / Gentle Elevation & Normal & Normal & 0 & 0 & 0 & 5 \\
\hline 2 & $\mathrm{No} / \mathrm{No}$ & Normal & Normal & 1 & 1 & 1 & 4 \\
\hline 3 & No / No & $\mathrm{N} / \mathrm{A}$ & $\mathrm{N} / \mathrm{A}$ & 5 & 6 & 6 & 0 \\
\hline 4 & No / No & Normal & Normal & 0 & 0 & 0 & 4 \\
\hline 5 & No / No & Normal & Normal & 0 & 0 & 0 & 1 \\
\hline 6 & No / No & Normal & Loss of R Vision & 0 & 2 & 2 & 2 \\
\hline 7 & No / No & Normal & Normal & 0 & 0 & 0 & 1 \\
\hline 8 & No / No & Normal & Normal & 0 & 1 & 0 & 3 \\
\hline 9 & No / Gentle & Normal & Normal & 0 & 0 & 0 & 2.2 \\
\hline 10 & No / No & Normal & Normal & 0 & 0 & 0 & 1 \\
\hline 11 & No / No & Normal & Normal & 0 & 1 & 1 & 1 \\
\hline
\end{tabular}

Abbreviations: mRS: modified Rankin Scale, N/A: not available.

aneurysms must project medially, superiorly, superomedially, or inferomedially to be accessed contralaterally. Those that project laterally or superolaterally are draped by the optic nerve, are difficult to visualize, and require more optic nerve manipulation for clipping. Therefore, the dome projection of the contralateral aneurysm must be carefully analyzed when selecting patients for this approach.

The major risk of a single operation for bilateral ophthalmic segment aneurysms is the risk to both optic nerves. Visual loss affecting both nerves is potentially devastating. Only one patient in this experience had a vision change related to surgery, and this occurred in the eye ipsilateral to the craniotomy. Anterior clinoidectomy appears to be the greatest risk to vision, due to drilling the clinoid process (i.e., heat or vibration), injury to small perforators on the optic nerve, direct manipulation during the dissection of the distal dural rings, or some combination of factors. A contralateral approach that does not require clinoidectomy decreases the risk of a new visual deficit. The good outcomes with contralateral vision in our experience may also relate to the smaller sizes and diminished complexity of the contralateral aneurysms. Although we observed no ipsilateral optic nerve morbidity related to contralateral clipping in this experience, we have observed it in our larger contralateral aneurysm clipping experience in one patient. In that patient, a large clip (25 mm) was applied through the interoptic triangle to a contralateral posterior communicating artery aneurysm, and the lie of the clip's shank across the ipsilateral optic nerve resulted in a new, bilateral visual deficit from occlusion of perforating arteries that supplied the superior aspect of the ipsilateral optic nerve, affecting ipsilateral nerve fibers as well as contralateral fibers in von Willebrand's knee. Therefore, short or mini clips are recommended for contralateral clipping in order to keep the clips off the ipsilateral optic nerve.
Intraoperative rupture during contralateral clipping is another potential hazard with this approach. Proximal control in the neck is typically not accessible with the head turned and the neck covered in drapes. Furthermore, the clinoidal segment of ICA is not accessible intracranially on the contralateral side for proximal control. Therefore, this approach is limited to unruptured aneurysms, or cases where the ipsilateral aneurysm is clearly the ruptured aneurysm. Only two of our patients had ruptured aneurysms and the side of the ruptured aneurysm was clear either from the size of the aneurysms or the pattern of subarachnoid blood on CT scans. In addition to selecting patients with unruptured contralateral aneurysms, one should also select small aneurysms with simple neck anatomy that do not require temporary clipping or complex clip configurations.

As the surgical indications for paraclinoidal aneurysms decrease with increasing endovascular options, the technical skills required for anterior clinoidectomy will be more difficult to develop and maintain. There are nuances to this complex anatomy and these clinoidectomy techniques that demand study in cadaveric dissection and steady clinical application. Complete clinoidectomy and thorough dural ring dissection open many options for direct clip repair of the ICA with complex paraclinoidal aneurysms, and these techniques should not be abandonned for novel endovascular devices with undetermined long-term efficacy. Surgical clipping continues to offer advantages in releasing compression of the optic nerve, completely occluding the aneurysm neck, providing a durable repair, and avoiding antiplatelet agents in the setting of acute aneurysm rupture. This experience demonstrates that contralateral clipping of ophthalmic segment aneurysms is a straightforward addition to ipsilateral clipping of ophthalmic segment aneurysms, provided that both aneurysms are carefully selected for surgical management. 

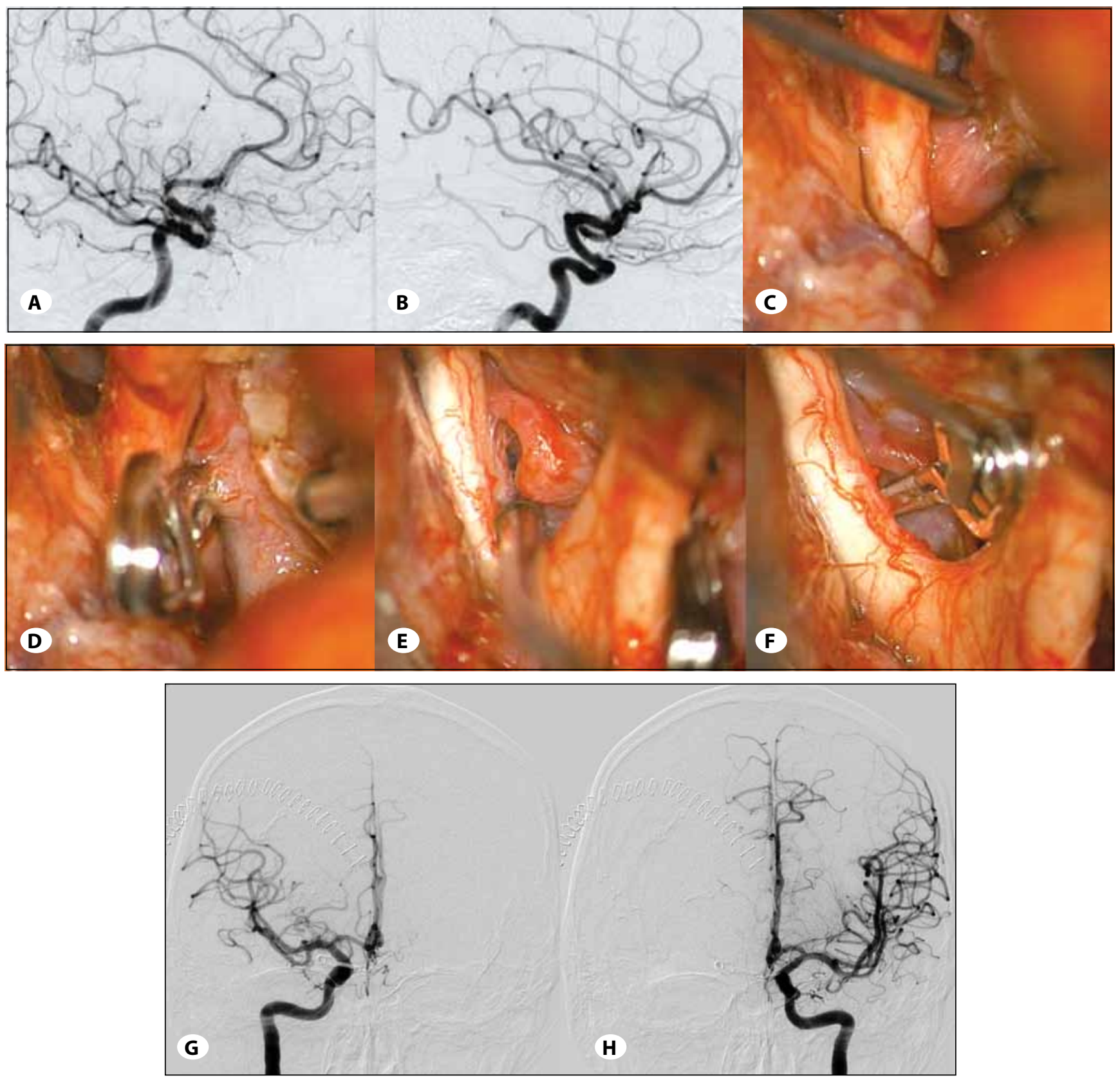

Figure 2: Case Example 1. This 24-year old man was diagnosed with an incidental intracranial aneurysm during the evaluation of schizophrenia. His MRI revealed a 5-mm medially projecting right internal carotid artery aneurysm at the origin of the superior hypophyseal artery. He was further evaluated with a cerebral angiogram (A) Right Common Carotid Injection, lateral view; B) Left Common Carotid Injection, lateral view) that confirmed a right ophthalmic segment broad base aneurysm and another $2 \mathrm{~mm}$ ophthalmic aneurysm on the left internal carotid artery. C) After right pterional craniotomy and clinoidectomy was performed, the ophthalmic artery was followed to expose the proximal and distal neck of the ipsilateral aneurysm and D) a straight clip was applied across the base of the aneurysm. E) The interoptic triangle was then opened and dissection to the contralateral carotid artery exposed the contralateral aneurysm. F) A curved clip was used to occlude the contralateral aneurysm. Postoperative angiogram demonstrated patency of the parent vessels and complete occlusion of both aneurysms (G) Right Common Carotid Injection, anteroposterior view; $\mathbf{H}$ ) Left Common Carotid Injection, anteroposterior view). The patient was discharged home neurologically intact 3 days after surgery. 

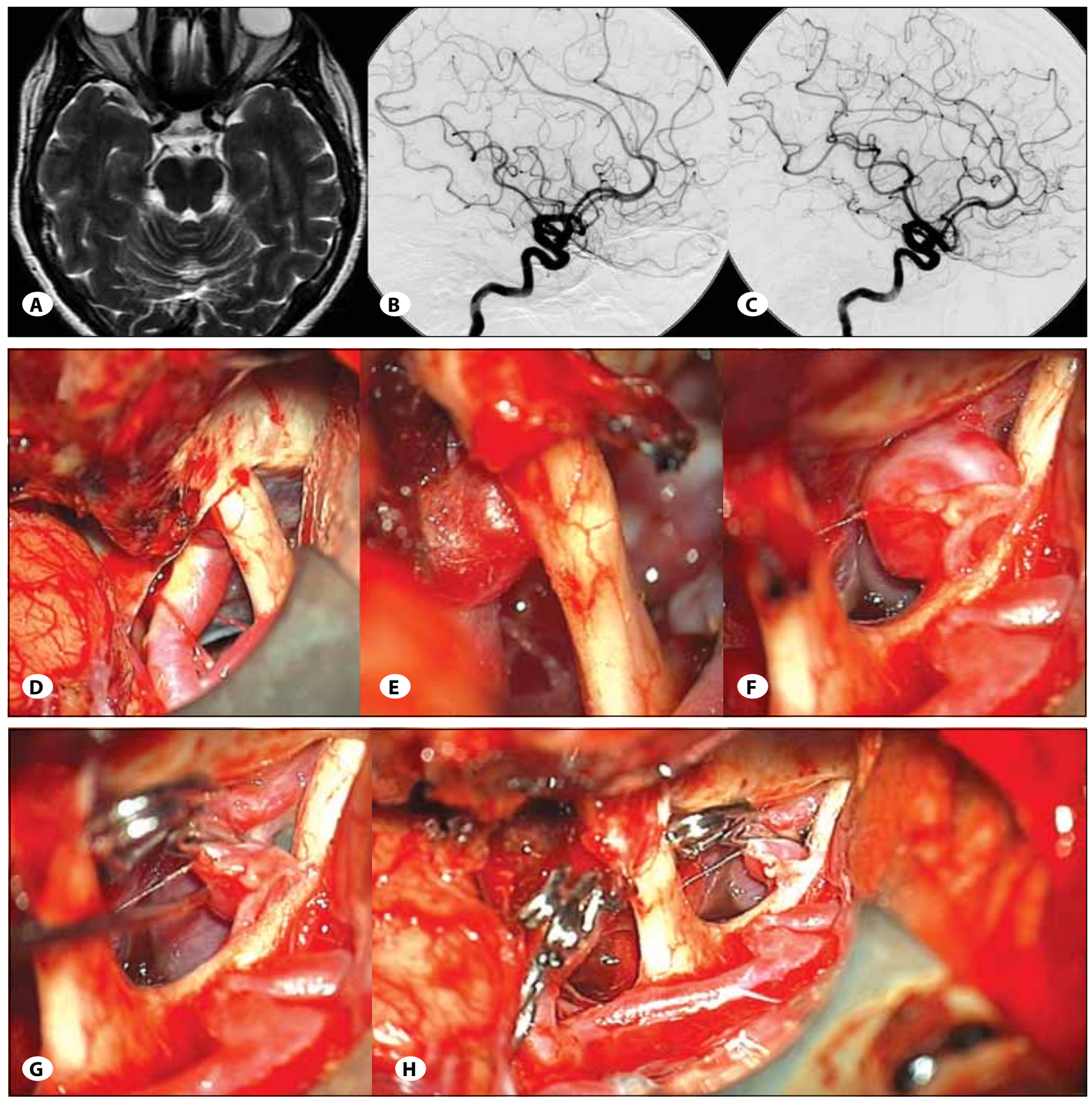

Figure 3: Case example 2. This 61-year old woman was incidentally diagnosed with unruptured bilateral OphA aneurysms during the evaluation of a chronic head and neck pain. A) Her T2 weighted axial brain MRI revealed bilateral 6mm OphA aneurysms. A cerebral angiogram B) Right Internal Carotid Injection, lateral view; C) Left Internal Carotid Injection, lateral view) demonstrated the anatomy of these mirror aneurysms. D) A left pterional craniotomy and a sylvian fissure split exposed the carotid artery and revealed the aneurysm hidden by the anterior clinoid process. E) A clinoidectomy was performed and the distal dural ring was circumferentially dissected, exposing the ophthalmic artery and the neck of the aneurysm. F) The contralateral aneurysm could be seen projecting medially in the interoptic triangle. G) The adhesions between the contralateral aneurysm and the optic nerve were dissected, allowing complete visualization of the aneurysm neck that was clipped with a slightly curved Yasargil clip. H) The ipsilateral aneurysm was clipped using a $9 \mathrm{~mm}$ straight aneurysm clip. Two additional straight clips were stacked underneath this primary clip in order to remove a small "dog ear" at the ophthalmic origin. 


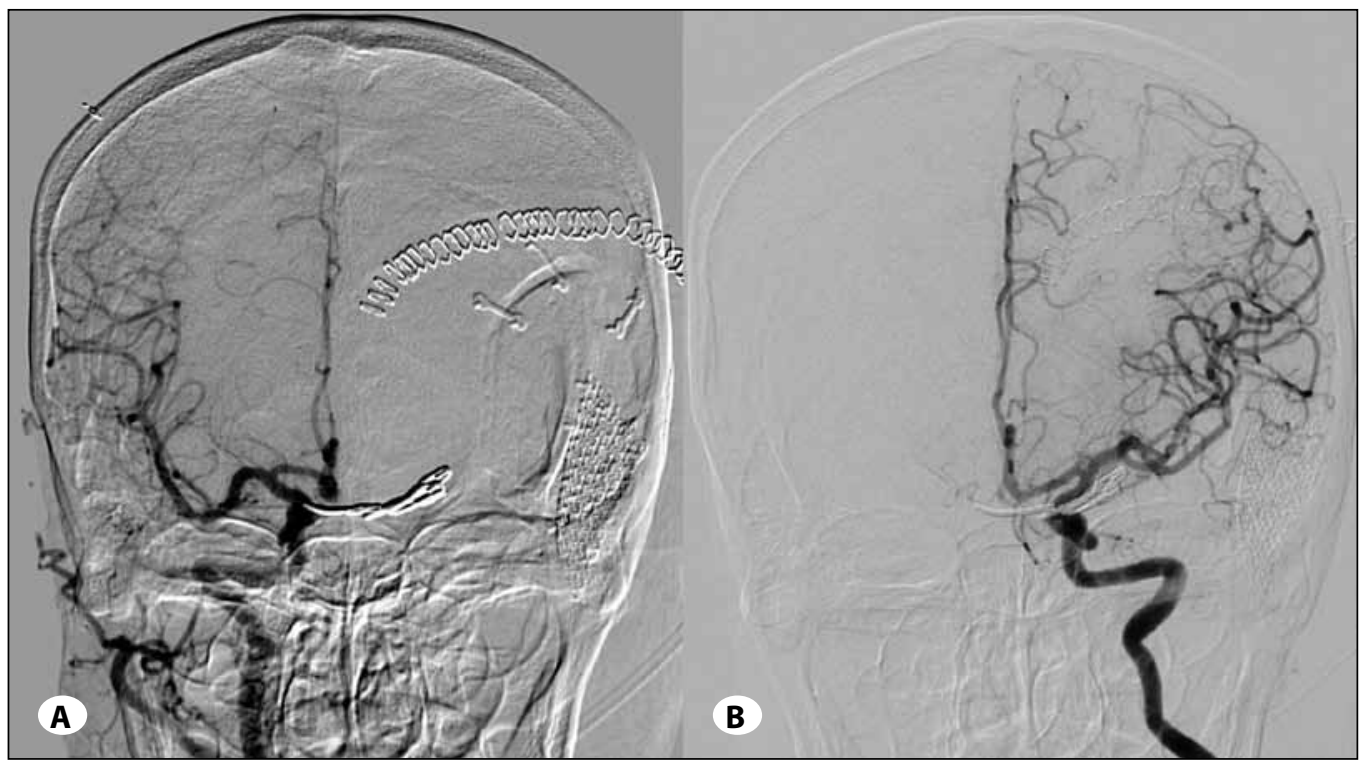

Figure 4: Case Example 2. A postoperative angiogram (A) Right Common Carotid Injection, anteroposterior view; B) Left Internal Carotid Injection, anteroposterior view) showed complete occlusion of both aneurysms and patency of the parent vessels. The patient was discharged home neurologically intact.

\section{REFERENCES}

1. Day AL: Aneurysms of the ophthalmic segment: A clinical and anatomical analysis. J Neurosurg 72:677-691, 1990

2. De Oliveira E, Tedeschi $H$, Siqueira MG, Ono $M$, Fretes $C$, Rhoton AL Jr, Peace DA: Anatomical and technical aspects of the contralateral approach for multiple aneurysms. Acta Neurochir (Wien) 138:1-11, 1996

3. Dolenc V: A combined epi- and subdural direct approach to carotid-ophtalmic artery aneurysms. J Neurosurg 62:667-672, 1985

4. Erdogmus S, Govsa F: Anatomic features of the intracranial and intracanalicular portions of ophthalmic artery: For the surgical procedures. Neurosurg Rev 29(3):213-218, 2006

5. Fries G, Perneczky A, van Lindert E, Bahadori-Mortasawi F: Contralateral and ipsilateral microsurgical approaches to carotidophthalmic aneurysms. Neurosurgery 41:333-343, 1997

6. Gibo $\mathrm{H}$, Lenkey $\mathrm{C}$, Rhoton AL Jr: Microsurgical anatomy of the supraclinoid portion of the internal carotid artery. J Neurosurg 55:560-574, 1981

7. Ide M, Hagiwara S, Tanaka N, Kawamura H: Bilateral ophthalmic segment "kissing" aneurysms presenting with subarachnoid hemorrhage--case report. Neurol Med Chir 42(10):427-430, 2002

8. Kobayashi S, Kyoshima K, Gibo H, Hegde SA, Takamae T, Sugita K: Carotid cave aneurysms of the internal carotid artery. J Neurosurg 70:216-221, 1989

9. Kothandaram P, Dawson BH, Kruyt RC: Carotid-ophthalmic aneurysms: A study of 19 patients. J Neurosurg 34:544-548, 1971

10. Milenkovic Z, Gopic H, Antovic P, Jovicic V, Petrovic B: Contralateral pterional approach to a carotid-ophthalmic aneurysm ruptured at surgery: A case report. J Neurosurg $57: 823-825,1982$
11. Nakao S, Kikuchi H, Takahashi N: Successful clipping of carotidophthalmic aneurysms through a contralateral pterional approach. J Neurosurg 54:532-536, 1981

12. Nanda A, Javalkar V: Microneurosurgical management of ophthalmic segment of the internal carotid artery aneurysms: Single-surgeon operative experience from Louisiana State University, Shreveport. Neurosurgery 68(2):355-370, 2011

13. Nishio S, Matsushima T, Fukui M, Sawada K, Kitamura K: Microsurgical anatomy around the origin of the ophthalmic artery with reference to contralateral pterional surgical approach to the carotidophthalmic aneurysm. Acta Neurochir (Wien) 76:82-89, 1985

14. Oikawa S, Kyoshima K, Kobayashi S: Surgical anatomy of the juxta-dural ring area. J Neurosurg 89:250-254, 1998

15. Oshiro EM, Rini DA, Tamargo RJ: Contralateral approaches to bilateral cerebral aneurysms: A microsurgical anatomical study. J Neurosurg 87:163-169, 1997

16. Perneczky A, Knosp E, Vorkapic P, Czech T: Direct surgical approach to infraclinoidal aneurysms. Acta Neurochir (Wien) 76:36-44, 1985

17. Shiokawa Y, Aoki N, Saito I, Mizutani H: Combined contralateral pterional and interhemispheric approach to a subchiasmal carotid-ophthalmic aneurysm. Acta Neurochir (Wien) 93:154- 158, 1988

18. Vajda J, Juhasz J, Pasztor E, Nyary I: Contralateral approach to bilateral and ophthalmic aneurysms. Neurosurgery 22: 662-668, 1988

19. Yasargil MG, Gasser JC, Hodosh RM, Rankin TV: Carotidophthalmic aneurysms: Direct microsurgical approach. Surg Neurol 8:155-165, 1977 